\title{
Developing female middle-managers in Australian universities
}

Associate Professor Michelle Wallace PhD, Graduate College of Management

Southern Cross University, NSW, Australia

Michelle Wallace is Associate Professor in Human Resources in the Graduate College of Management, Southern Cross University. Prior to joining academe she was involved in human resource development roles in the public sector.

Michelle's research interests focus on the specific HR practices of attraction, recruitment and retention, strategic HRM, HRM in Asian contexts and organizational change. She has researched issues surrounding women, work and human resource practices in a number of contexts and also researches transnational teaching and learning from the perspective of academic staff development.

Dr Teresa Marchant, Graduate College of Management, Southern Cross University, NSW, Australia

Dr Teresa Marchant is a lecturer and project officer in the Graduate College of Management, Southern Cross University. After a career in marketing including at IBM, she was the first to complete a PhD in the Department of Human Resource Management and Employment Relations at the University of Southern Queensland. Most recently she has been developing scholarly materials for the national public sector management program and is currently researching HRD, gender and higher education.

Michelle Wallace is corresponding author.

Graduate College of Management,

Southern Cross University,

PO Box 42 Tweed Heads NSW 2485, Australia

Tel: +61 755069366

Fax: +61 755069301

michelle.wallace@scu.edu.au

A preliminary analysis of this research was presented at ATN/WEXDEV International Conference, Change in climate? Prospects for gender equity in Universities, 11-13 April 2006, Adelaide, South Australia.

Word count: 5500 


\title{
Developing female middle-managers in Australian universities.
}

\begin{abstract}
Universities should be developing female middle-managers for reasons of gender balance (Aitkin 2001), the skills shortage, pending mass retirements (Chesterman 2004) and sustainable, postbureaucratic organizations (Kira and Forslin 2008). Investigating the learning and development of women managers is timely. Research assumes that women in academe have the qualifications, experience and skills for management. Is this the case? The paper provides the first national demographic and development profile of women middle-managers in academic and the researchneglected administrative streams in Australian universities, with a sample of 342 women (46\% response rate). Age is a particularly notable demographic with the majority of academics within five to ten years of retirement. Nearly sixty percent of academics experienced few current development opportunities and their discipline-based qualifications did not prepare them for management. However, a greater number of administrative managers received relevant preparatory training. Once in their current management roles women experienced markedly fewer development opportunities. If higher education institutions are learning organizations, continuous learning should be evident (Watkins 2005). Our research shows this is far from the case.
\end{abstract}

Keywords: gender, middle-managers, skills shortage, learning 


\section{Introduction}

Gender issues in the university workforce (Aitkin 2001; Allport 1996, Australian Vice Chancellors Committee (AVCC) 2004; Eveline 2004), predicted mass retirements in the sector over the next five to ten years (Chesterman 2004) coupled with a need for ongoing leadership and concerns about a looming shortage of senior academics (Sydney Morning Herald 28 February 2009) signal that an investigation of women university middle-managers' development is timely. The number of females and males employed in Australian higher education is roughly equal but women hold only $24 \%$ of managerial positions (AVCC 2004), and unpublished figures from Universities Australia indicate this proportion has not increased. Women may be a rich but untapped source of skills and knowledge. Much research on the advancement of women in academe assumes they already have the qualifications, experience and skills to assume management roles. However it has been identified that the leadership attitudes, performance and development needs of women middle-managers in universities have been neglected (Joyner and Preston 1998; Probert 2005). While the development of staff has received attention in terms of teaching, and to a lesser extent, research (Akerlind 2005; Padilla 2008) there is a gap in the literature regarding female academics' development in their administrative or management roles, particularly at the middle levels. There is also a marked gap regarding the development experiences of women working in the administrative streams in universities.

Gender issues have been widely explored when examining senior women's leadership in academe (Aitkin 2001; Allport 1996; Blackmore and Sachs 2000; 2001; Currie and Thiele 2001; Ramsay 2000). For example, managerialism and a neo-liberal political rationality had mixed effects on women's career advancement (Blackmore and Sachs 2001). Expansion of the sector to service skilled labor needs of the economy created opportunities for women to move into and up in higher education but on the other hand wage decentralization in Australia served to entrench gender inequity in wages (van Gellecum, Baxter and Western 2008). The embededness of human resource development opportunities as part of such structure, culture and changes in the higher education context have not been fully explored. Human resource development (HRD) encompasses formal education and training, including induction, management and leadership development and less formal, situated processes such as on-the-job learning, mentoring, coaching and career development (Werner and DeSimone 2006). In the university context, women's development has different meanings for individuals including increasing performance to avoid or reduce anxiety or inadequacy and desire for challenge and satisfaction (Akerlind 2005). This paper is particularly interested in women's development in the context of emerging ideas about sustainability in the knowledge economy and the role of learning and development (Kamoche 2007).

\section{Organization sustainability and human resource development}

Organizations are transitioning to post-bureaucratic forms enhancing and facilitating learning and development (Kira and Forslin 2008). Sustainable organizations must develop and retain skilled staff. The knowledge economy requires a quality workforce, rendered more precious by the 
shrinking labour pool, and this is perhaps no more salient than in the university sector with its tradition of 'older and wiser experts'. Resource based strategy is usurping the long-established market-based view of HRD, recognizing that developing human capital through strategic education and skill training is a sound investment. Intellectual and social capital includes internal workplace capacity in the form of knowledge, skills and a positive team culture to engage, motivate and retain staff. Out-moded thinking controls costs by reducing staff numbers, limits investment in learning and development and has a narrow concern with meeting stakeholder expectations (Benn, Dunphy, and Griffiths 2007).

Australian organizations are not well prepared for the labour crisis (Asquith, Sardo and Begley 2008). Even though many cite it as an issue, remarkably few have explicit diversity management strategies or targeted plans to recruit, better manage and retain women or older employees (Dychtwald and Baxter 2007). The diversity management literature provides ample empirical evidence for organizations to develop their women managers (Howell, Buttigleg and Webber 2006). These arguments are magnified in the face of the skills shortage. Attracting and retaining staff are two advantages accruing to organizations with good gender equity records (Equal Opportunity for Women in the Workplace Agency (EOWA) 2008).

HRD for women university managers is important for increasing skills and competence (UNESCO 2002). Individuals increase their human capital through education and training (Kaufman 1994, in Wang and Holton 2005). Increased productivity, expertise and rewards accrue to individuals with more human capital (Wayne, Liden, Kraimer, and Graf 1999). Much of the literature regarding the culture of organizations, including universities, assumes that women already have the requisite human capital in the form of qualifications, experience and specific skills to assume management roles, and that access to development opportunities has not been problematic (Krefting 2003; McDonald 2006; Burke, Burgess and Fallon 2006).

On the other hand, Joyner and Preston (1998) have identified that leadership attitudes, performance and development needs of women managers in universities were neglected. Lack of training for university managers has been noted in the UK (Deem 2003). One US study (Rosser 2004) covered middle-managers of both genders, addressing job satisfaction and retention. Our study adds to the knowledge base of learning and development for women middle-managers in universities. Women's individual experience of academic development have been explored in small qualitative studies (Akerlind 2005; Jo 2008), and individual Australian institutions (White 2003; Wallace 2006). In Scotland a 'feminised academic ghetto' is partly attributed to a lack of human capital in the form of appropriate qualifications (Ebner 2007, p. 4). The limited amount of existing research notes that middle-managers such as deans, heads of department and associate professors receive little development for management and leadership roles. Furthermore, Probert (2005, p. 58), in discussing the under-representation of women in Australian university hierarchies, stated that, "women have less "human capital" than men, measured in terms of formal qualifications and work experience'. 
Systematic, quantitative research into HRD for women middle-managers is needed, but there has been little investigation of either middle-managers or HRD in the higher education and other literature.

This paper examines demographics and HRD experiences of academic and administrative, female middle-managers in Australian universities. We focus on middle rather than senior managers because the latter have been well documented in Australia (Blackmore and Sachs 2000; 2001; Chesterman, Ross-Smith and Peters 2003) and overseas (Doherty and Manfredi 2006; Ebner 2007; Gopinathan 2007; Krefting 2003; Niven 2007; van den Brink, Brouns, and Waslander 2006). Also, the impending impact of generational change, where the relatively small number of senior women executives will retire (Chesterman et al. 2003; 2006), raises the question: who is being developed to take their place?

\section{What do we know about middle-managers?}

Defining middle-managers is complex as they are a heterogeneous group (Kramar 1990). There is some agreement that middle-managers are above first line supervisors (such as team leaders) and below the senior executive which includes the chief executive office and their immediate reports (Vice Chancellors and Deputy Vice Chancellors in the higher education context) (Roomkin 1989; Veiga 1983). Managers in the academic stream have been defined as dean or associate dean, department or school head, deputy head or other academics working in positions entailing administrative responsibilities (Subramaniam 2003, p. 524). Academic managers are responsible for primary academic units and are operationally significant in teaching and research (Santiago, Carvalho, Amaral, and Meek 2006). Our study included school heads who are technically 'first line supervisors', but given the qualifications and responsibilities of the role we argue they are closer to middle-managers than team leaders in the university context. Managers in the administrative stream have been defined as academic or administrative support personnel including directors and coordinators of admissions, institutional research, registrars, computing and technology, human resources, alumni affairs, student services, and development. Middlemanagers in higher education are the 'unsung professionals in the academy yet they interact and participate with students, faculty members and the public and reflect the institution's overall spirit and vitality' (Rosser 2004, p. 317).

Middle-managers need learning and development to improve in their current roles and prepare for more challenging senior executive positions. Professional and career development is significant to their institutional work life (Rosser 2004). Women university managers are more interested in staff development and teaching than men who emphasize finance and research (Deem 2003). University middle-managers want equity in institutional and departmental selection practices for internal and external candidates, to improve prospects for sideways and upwards career movement (Rosser 2004). Access to HRD improves such prospects (Werner \& DeSimone 2006). 


\section{Impact of changing university context on middle-managers}

In addition to the gender issue is the question of middle-managers' capacity to perform in the changing university environment (Subramaniam 2003) and contribute to sustainable organizations. Managerialism creates new problems for administrative roles in higher education (Blättel-Mink 2008). Middle-managers are at the cutting edge of implementing managerialist policies, adding pressure to become more professional, with a new focus on performance measures other than traditional teaching and research. They are expected to have skills in strategic management to define mission and vision, manage financial, human and informational resources and exhibit more business-like capacity for leadership and management. Their roles are 'one of the most critical and problematic activities (Santiago et al. 2006, p. 241).

Further, 'staff in such administrative positions are mainly preoccupied by a constant and hectic process of routinization, standardization and codification of academic work in the effort to maintain 'quality' against increasing staff-student ratios' (Lafferty and Fleming 2000, in Subramaniam 2003, p. 507). Administrative staff have also experienced change, professionalizing their roles, and increasing their qualifications to degree status with new professional bodies and standards of practice (Santiago et al. 2006). A focus on HRD of those in middle management roles is timely.

The central questions addressed in this paper are thus:

- What is the demographic profile of female middle-managers?

- What human capital do they have and are there differences between academic and administrative streams?

- Do they participate in learning and development opportunities that enhance their current roles and prepare them for contributing to sustainability in a complex and changing university environment?

- What are the implications for women's advancement to senior executive level and for the skills shortage

- Does their experience reflect rhetoric about resource based strategy, retention and learning?

\section{METHODOLOGY}

\section{Sampling frame and survey}

A survey was mailed to all women identified as middle-managers (academic and administrative) from the (then) AVCC (2004) website List of Senior University Women. Listing is by invitation or nomination. The Australian university hierarchy ranks academics on a five level scale from A (lowest) to E (highest). Administrative staff are called higher education workers (HEW) ranked from 1 (lowest) to 10 (highest). Administrative positions extend beyond HEW 10 but are not ranked past that level. The List of Senior University Women is open to academics from Levels C, D and $\mathrm{E}$ and administrative staff from HEW 10 or above. 
The population is a relatively elite cohort since the top three academic and administrative levels represent only $32 \%$ of female academic and $6 \%$ of female administrative staff (AVCC 2006). The survey was completed by early 2005. Vice Chancellors, Deputy Vice Chancellors, Pro Vice Chancellors (academic and administrative) and Executive Deans were excluded as senior executives but women in roles such as deans, heads of academic/research or administrative departments were included (Rosser 2004; Subramaniam 2003).

Survey questions combined closed and open-ended responses involving demographics such as age, tenure, qualifications and university type. University type follows Marginson's (1999) typology. 'Sandstones' ( 6 in all) are the universities founded mainly in the $19^{\text {th }}$ century and the first of their kind in each state, for example The University of Queensland and The University of Tasmania. 'Redbricks' (3) are generally the next oldest, for example Monash University and The Australian National University. 'Gumtrees' (10) are generally those in what were fringe urban areas in the 1950s and 60s and in established rural cities, for example, Flinders University and James Cook University. 'Unitechs' (5) are the former Institutes of Technology, for example, Curtin University of Technology and the University of Technology, Sydney and 'New Universities' (14) are those created since 1989, for example the University of Ballarat and University of Southern Queensland. Participants were asked to detail HRD activities experienced in preparation for current and subsequent roles and asked to evaluate the activities' usefulness. Other questions were asked about satisfaction and dissatisfaction with management roles and results relating to this part of the survey will be reported elsewhere.

A total of 750 surveys was distributed with 342 usable replies (academic $n=170$, administrative $n$ $=172$ ), giving a response rate of $46 \%$. This is comparable to Rosser (2004) with a $50 \%$ response rate from university middle-managers in the US, and towards the high end of common mail survey response rates (Neuman 1994). The relatively high response rate suggests that these 'unsung professionals' (Rosser 2004, p. 317) were keen to be heard.

\section{Sample details}

The women came from the following university types: New (28\%), Sandstone (25\%), Unitec (23\%), Gumtrees (17\%) and Redbrick (7\%). The delimitation of the sample frame meant we would expect women to be confined to Level C and above (academic) and HEW 10 and above (administrative), however there were some women from lower levels. Academic managers were level E, Professor (35\%), level D, Associate Professor (29\%) Level C, Senior Lecturer (29\%), and level B/A, Lecturers/Associate Lecturer (7\%). For administrative managers, above HEW 10 (32\%), HEW 10 (49\%), HEW 9 (10\%), HEW 8 (7\%). Management role: The largest category amongst academic managers was head of school or department (43\%) followed by head of research centre $(15 \%)$, dean (14\%), head of administrative department $(8 \%)$, and Deputy/Acting/Associate/Sub Dean (4\%). For the administrative stream, head of administrative section or department $(46 \%)$, or administrative directorate $(20 \%)$ or administrative team $(13 \%)$ 
with a smattering of project managers, laboratory managers, faculty managers, executive officers and internal consultants.

\section{PROFILE OF THE WOMEN}

The following results profile key demographics of female middle-managers. They may not all add to $100 \%$ because of rounding and a small number of outliers.

\section{Age, tenure and time in current level}

Age, tenure and period at current level are shown in Table I. Age: The most notable feature of these results is the age of the academics, with virtually the entire group being over 30 and well over half $(61 \%)$ over 51 . Given that most of these women can access superannuation at 55 , imminent retirement of a relatively large cohort of female academic middle-managers is possible, although perhaps less probable as recent changes to superannuation policy encourage employees to stay in the workforce. These women may have at least five or ten years remaining, depending on how proactive and imaginative universities are in managing phased retirement. The age distribution was younger for administrative women with $17 \%$ still in their thirties. Nonetheless nearly $40 \%$ of administrative managers were also 51 or older.

Table I Age, tenure and period at current level

\begin{tabular}{|c|c|c|c|c|}
\hline \multirow[t]{2}{*}{ Years } & \multicolumn{2}{|c|}{ Academic } & \multicolumn{2}{|c|}{ Administrative } \\
\hline & Number & $\%$ & Number & $\%$ \\
\hline \multicolumn{5}{|c|}{ Age (years) } \\
\hline $61-70$ & 4 & 2 & 2 & 1 \\
\hline $51-60$ & 101 & 59 & 68 & 39 \\
\hline $41-50$ & 60 & 35 & 70 & 40 \\
\hline $31-40$ & 5 & 3 & 30 & 17 \\
\hline \multicolumn{5}{|c|}{ Tenure (years worked at current university) } \\
\hline $15+$ & 58 & 34 & 36 & 21 \\
\hline $9-15$ & 51 & 30 & 61 & 35 \\
\hline $5-8$ & 22 & 13 & 16 & 9 \\
\hline $3-5$ & 29 & 17 & 38 & 22 \\
\hline $1-2$ & 10 & 6 & 21 & 12 \\
\hline \multicolumn{5}{|c|}{ Years at current level } \\
\hline $8+$ & 32 & 19 & 34 & 20 \\
\hline $6-8$ & 17 & 10 & 30 & 17 \\
\hline $3-5$ & 74 & 44 & 55 & 32 \\
\hline $1-2$ & 46 & 27 & 53 & 31 \\
\hline
\end{tabular}

It would be hard to find any dissenting literature about the ageing workforce being a significant issue for developed economies. The number of retirees is increasing and new entrants decreasing (OECD 2004). Some claim it will be a 'crisis of unparalleled proportions' (Dychtwald and Baxter 2007 p. 325). 
Tenure at university: As shown in Table I, academic and administrative managers tend to have long tenure of 15 years or more for one in three academic and one in five administrative managers. Well over half of both groups had 8 years or more in their current university. Compared to academic managers, more administrative managers were relatively new.

Time at current level: The distribution of academic and administrative managers on years at current level was similar. Of note was that for both groups nearly one third had been at the same level for over 6 years and around one fifth for over 8 years. Operational definitions of career plateau vary from five through seven to ten years in the same position, at the same level or subjectively, as a perception of a low likelihood of future moves up the hierarchy (Chao 1990). We did not measure women's perceptions, but by some standards (i.e. time in same position) they may be plateaued.

Longevity of tenure and years at level may reflect mobility issues for women, particularly for those at non-metropolitan universities. Castleman et al. (1995) identified geographic mobility as a key restraining factor in career development. Longevity also indicates an experienced cohort, but the number of women who have been at level for over six years indicates they have not been promoted, or have not applied for promotion. This raises serious questions about the pipeline effect in women's advancement to senior executive positions.

\section{Human capital}

One way of measuring human capital is formal qualifications. Table II summarizes highest educational qualifications and qualifications directly relevant to the management role.

Table II Highest qualifications and relevance to management role

\begin{tabular}{llllc}
\hline Highest qualifications & \multicolumn{2}{c}{ Academic } & \multicolumn{2}{c}{ Administrative } \\
\hline & Number & \% & Number & \% \\
\hline PhD & 122 & 72 & 12 & 7 \\
Masters degree & 33 & 19 & 71 & 41 \\
Bachelors degree & 6 & 3 & 42 & 24 \\
Graduate Diploma & 5 & 3 & 33 & 19 \\
Qualifications directly related to current management role & & & & \\
PhD & 95 & 56 & 7 & 4 \\
Masters & 32 & 19 & 65 & 39 \\
No management qualifications directly related to current role* & 12 & 7 & - & - \\
Professional development and experience, professional qualification, & 13 & 8 & 44 & 27 \\
graduate certificate or diploma & & & & 24 \\
Bachelors' degree & 6 & 4 & 40 & 24
\end{tabular}

\footnotetext{
* Note respondents were asked to choose from a list of formal Australian qualifications, which they perceived to be relevant to their management role. Therefore the notion of a management qualification in this study is a formal certificate, degree, or diploma where discipline content was defined as management related by the respondent.
} 
The percentage of academic women with a $\mathrm{PhD}$ in our study is higher than the national average in Australian universities of 53\% (Probert, Ewer and Whiting 1998). This may reflect high ambition levels of these women and the qualifications required to be an academic manager. Of the academic managers with a $\mathrm{PhD}$, most perceived a relationship to the academic leadership component of their current role but few perceived relevance to the management and administration component. This suggests that academic women managers need $\mathrm{PhDs}$ for credibility but could benefit from specific management qualifications such as an MBA, Master of Public Administration, or other degrees that address management in the higher education context, and other management development opportunities. The literature is relatively silent on this issue.

The predominant highest-level qualification for administrative managers was a masters degree followed by a bachelors degree and graduate diploma and none had no management qualifications, indicating a high level of human capital. This accords with Santiago et al. (2006) who found increasing professionalization of administrative managers' work. More administrative managers perceived their qualification as directly related to their current role. Of the seventy-one women with a masters degree, sixty-five perceived the qualification was directly relevant, and of the fortytwo women with bachelors degrees, forty saw a direct relationship. We did not ask in which field of study the masters or bachelors degrees were. Since the women were asked to nominate relevance, the assumption is that the degree was in administration, management or similar, however future research could ask for details of the qualification to investigate further whether degrees in various disciplines are perceived to be relevant.

\section{Human resource development opportunities}

Table III offers additional human capital information by way of HRD opportunities and activity. The women looked back to development activities that prepared them for their current management role and development since taking up their current role. Percentages add to more than $100 \%$ as women could nominate more than one response.

Table III HRD activities that prepared women for their current management roles

\begin{tabular}{|c|c|c|c|c|}
\hline Type of HRD activity & \multicolumn{2}{|c|}{$\begin{array}{c}\text { Academic } \\
(\%)\end{array}$} & \multicolumn{2}{|c|}{$\begin{array}{c}\text { Administrative } \\
(\%)\end{array}$} \\
\hline Experience & 29 & 46 & 36 & 48 \\
\hline No relevant activities & 25 & 40 & 13 & 18 \\
\hline Mentoring & 56 & 33 & 56 & 35 \\
\hline In-house management training & 55 & 32 & 62 & 36 \\
\hline In-house leadership development program & 41 & 24 & 45 & 26 \\
\hline AVCC leadership or management program & 27 & 16 & 38 & 22 \\
\hline Short courses outside university & 17 & 15 & 40 & 35 \\
\hline Degree or higher degree related to role & 26 & 15 & 72 & 42 \\
\hline In-house technical training & 13 & 8 & 18 & 10 \\
\hline Accredited professional qualification & 8 & 5 & 39 & 23 \\
\hline Australian Tertiary Education Management (ATEM) & 3 & 2 & 20 & 12 \\
\hline
\end{tabular}


leadership or management program

\section{Development activities since taking up current role}

$\begin{array}{lllll}\text { No relevant activities } & 23 & 59 & 18 & 35 \\ \text { Mentoring } & 49 & 39 & 49 & 28 \\ \text { In-house management training } & 65 & 38 & 72 & 42 \\ \text { In-house leadership development program } & 52 & 31 & 64 & 37 \\ \text { In-house technical training } & 25 & 15 & 35 & 20 \\ \text { Short courses outside university } & 17 & 15 & 43 & 35 \\ \text { Other professional development } & 6 & 15 & 16 & 31 \\ \text { AVCC leadership or management program } & 23 & 13 & 36 & 21 \\ \text { Education - formal/directed } & 4 & 10 & 13 & 25 \\ \text { Degree or higher degree in area related to role } & 8 & 5 & 25 & 14 \\ \text { ATEM leadership or management program } & 2 & 1 & 14 & 8 \\ \text { Accredited professional qualification } & 2 & 1 & 10 & 6\end{array}$

Our study was interested in formal HRD in women's preparation for management. Interestingly, experience, which is unstructured and informal, constituted the main preparation for current role. One striking feature here is the sizeable proportion of academic managers (40\%) and a lesser proportion of administrative managers (18\%) who received no preparatory development for their current roles, with comments such as '( $\mathrm{t}$ )his is the University of (Sandstone). It's sink or swim on your own here'.

In the open-ended section of the questionnaire three women mentioned that overseas experience had helped prepare them for their current management role. It is not clear whether this experience was in a management role, or for example, on a research sabbatical. The small number mentioning overseas experience contrasts with Ismail and Rasdi's (2007) claim about internationalization of higher education careers. It would be interesting to explore this issue in more depth. For example, the management literature on globalization indicates that overseas experience is an important component of management development in the globalised world (Caligiuri, Lazarova and Zehetbauer 2004; Forster 2000) and Castleman et al. (1995) reported that working at different universities and overseas accelerated female academic careers. The management literature proposes a range of models for internationalization of organizations and the role of management development in this process. It is beyond the scope of this paper but would be worth further investigation, particularly given the significance of overseas students, partner organisations and other aspects of internationalization in higher education.

Overall, academic managers received markedly less preparatory development than administrative managers. One reason may be academic managers are still perceived as mainly working in teaching and research spheres, seen as related to their academic training and competencies, while administrative managers are more involved with legislative, financial, human resource, industrial relations and other spheres with more external accountabilities. However, the overarching accountabilities related to measuring and micro-managing teaching and research are growing exponentially and research indicates that academic managers have similar quality, accreditation, 
financial, human resource, strategic planning and governance responsibilities to administrative managers (White 2004; Blackmore and Sachs 2004). The increasingly competitive climate also requires academic managers to be entrepreneurial in seeking new financial sources as government funding decreases. This involves business networking and contract negotiations, requiring skill sets unrelated to most academic disciplines. There also appears to be high levels of regulation and compliance in both streams with academic managers appearing less prepared, borne out by the comments in the survey. These results suggest the need for a new discipline of academic management expertise in terms of managerialism, or alternatively a change in culture from managerialism to learning and sustainability. In either case academic managers need more learning and development.

Administrative managers receive more development than their academic counterparts, particularly in terms of formal or external programs. This suggests that universities and their administrative middle-managers are more conscious of the management role's demands and the need to invest in relevant learning and development. The significance of the academics' management role appears to be under-rated. Contracting funds, greater workloads, fewer vacancies for new staff and more casual and part-time staff narrow academics' view of their development (Akerlind 2005). This needs more investigation.

For the $60 \%$ of academic managers with some prior development, mentoring was closely followed in frequency by in-house management training and in-house leadership development. Mentoring featured fairly equally as a development activity for both streams. Academic managers were more likely to mention (in open ended questions) that mentoring had been informal and spasmodic. For the $82 \%$ of administrative managers citing some development, their degree was most often mentioned followed by in-house management training, mentoring, in-house leadership development and short courses outside the university.

\section{Further development once in role}

In fulfilling their current responsibilities and looking forward to continued advancement and career development it could be expected that both academic and administrative managers had opportunities for further development. However, more academic and administrative managers stated they had not participated in development activities once in their current role: $59 \%$ percent for academic managers and 35\% for administrative managers (Table III). Considering the length of time at their current level it would be expected that they would have had at least some development in that time.

Of the $40 \%$ of academic managers who participated in current role development, the ranking accorded to mentoring and in-house management training was the same as 'before' responses. In other words, development activities did not increase commensurate with the new role and responsibility and did not differ in type. 
Where development had occurred, the most often-mentioned short courses were with the Australian Technology Network Women's Executive Development (ATN/WEXDEV), which apply to only six of thirty nine universities. There was a marked difference in responses between women from these technology universities and the few other universities reported to have specific development programs for women, and responses from other universities. Women who participated in structured, ongoing development programs had a more positive view of their universities and their own capacities.

Of the $35 \%$ of the administrative stream who participated in development once in middle management, in-house management training was cited most frequently, followed by in-house leadership development, short courses outside the university, mentoring and formal education. Mentoring was also discussed. More academics compared to administrative managers reported mentoring once in their current role. In-house technical training was reported more in current role for both streams.

Overall, it appears for this sample that female, middle-managers generally do not participate in much HRD. The administrative ranks tend to have a greater amount of preparatory management training and further development opportunities while in the middle management role.

\section{Discussion}

Our study reveals a picture of an ageing cohort of women with few development opportunities, little mobility between levels or universities, and a less than strategic approach to HRD on the part of higher education. These middle-managers still have between five to ten years of service and should be developed to take on senior executive roles if women's advancement in higher education is to continue. They should also be tasked with developing those at lower levels. Our study also shed some light on underlying processes and issues in relation to human capital of women middlemanagers. These women have relatively high human capital in terms of academic qualifications but it is clear that for academic women middle-managers, this may not be sufficient for their current, future or the changing role of management in higher education. It also seems unlikely that current qualifications will remain sufficient for administrative middle-managers. The lack of development goes against the rhetoric of lifelong learning and resource based strategy about investing in human resources (Garavan 2007). The lack of learning, development and mobility is of concern.

The Australian higher education sector needs to confront the ageing, lack of development and career immobility of female middle-managers, who still have at least five to ten years of service, and who supply the pipeline for senior executive positions. If women in the pipeline are not being developed, the persistent and consistent under-representation of women in senior management may continue. Organizations in future are likely to be competitive only to the extent that they are able to deal with these issues. Based on a US Department of Labour definition (Mosley and Conway-Desinger 2007, p. 7) many of these women are 'older workers'. They are exactly the group who should be targeted for solutions proposed for the skills shortage, including further 
learning and career development opportunities to retain and engage such workers (Asquith, Sardo and Begley 2008; OECD 2006). Even though older workers are provided fewer hours of training than younger workers, they have lower separation rates (Dychtwald and Baxter 2007) and should not be ignored as a source of expertise in the skills shortage.

Forecasting key workforce aging and retirement trends is an important strategy to ameliorate risks to organizations (Dychtwald and Baxter 2007). The implications are threefold. First these middlemanagers play a vital role in institutional memory and expertise and may be difficult to replace in their own right. Second they form the pipeline for more senior roles and increasing the' critical mass' of women at the top (Chesterman and Ross-Smith 2006). Third, the demographics, structure, values, and human capital of university employees largely determine the response that the institution can make to society (Altbach 1999; Schuster and Finkelstein 2006 in Padilla 2008) and our study suggests the message from Australian universities is not particularly positive in terms of lifelong learning or the development of women.

Our research suggests a fine tuning of Probert's (2005) statement that women have less human capital than men, since our women were highly qualified with lengthy experience. It would be interesting to compare the HRD opportunities of male and female managers since our research suggests it may not be lack of fixed human capital in terms of qualification and experience, but rather a lack of access to ongoing investment in and development of that human capital relevant to current and future roles.

In terms of replacing this cohort, heavy teaching workload, pressure to research and publish and low remuneration compared to the private sector, particularly in some professional disciplines, add to the difficulty of attracting staff (Lane 2008). Lack of promotion opportunities causes high turnover in Australian organizations (Asquith, Sardo and Begley 2008) and of middle-managers in US universities (Jo 2008). Universities risk staff losses through the lack of promotion and other development opportunities identified for female middle-managers, although the longevity of many women's roles in our study suggests otherwise. They seem to persist in their position at their universities despite limited learning and development.

\section{Limitations and scope for further research}

One of the core functions of universities is educating and developing people yet it seems that this may not apply to the female middle-managers in our study. The findings beg further investigation. Triangulating the results with perceptions of senior managers and examining universities' HRD policies would offer a more rounded picture. Further analysis of universities' claims to be learning organizations should have an HRD component.

The sampling frame used for the study is not an exhaustive list of women middle-managers in Australian universities. The AVCC List of Senior Women may bias the results towards those who are more ambitious. Such women may take more advantage of development opportunities, thus 
underestimating development in the population. We may have failed to present the experience of female middle-managers from lower hierarchical levels. Further research should target all female first level and middle-managers, and comparisons with males.

Given that around half of women contacted did not respond non-response bias is possible. It may be that non-respondents had sufficient HRD and did not respond since it was not an 'issue' for them. If this was the case our results may overstate the lack of development for university women middle-managers.

The survey method limits our understanding of women's lived experience of HRD to that which can be conveyed in a paper and pen mail survey with closed and brief open responses. Future research using in-depth qualitative methods could address additional questions including those raised by Akerlind (2005). Is there a natural point at which learning and development is finished? What range of feelings is associated with the various experiences of development? We would add to this exploring women's responses to their lack of development and limited preparation for current and more senior management roles.

In this paper our focus was on the academic management role yet many of the women still teach and research as well. We have not discussed how these multiple roles are accommodated or how they impact on the lack of development we have identified. This is a matter for further investigation.

\section{Recommendations}

Senior executives in universities should be aware of various development needs of staff, identify the most appropriate values and adapt practices accordingly. This particularly applies to the learning and development needs of female middle-managers as shown in our study. More HRD in all its various forms is strongly indicated. The exact nature of this development should be based on individual and organizational needs analysis (Werner and DeSimone 2006) but general implications are for a suitable qualification or other learning opportunity for academic women managers who are predominantly heads of schools. It may be that further qualifications in management, similar to those of women in the administrative stream, are desirable, recognizing that administrative management is a significant part of the role and quite distinct from research or teaching. However, having the highest possible academic qualification $(\mathrm{PhD})$, further qualifications at a lower level might seem unnecessary or undesirable, yet the literature and our results suggest otherwise. The extent and effect of different priorities for managing departments and varying approaches to motivating staff could be considered more explicitly in the preparation of manager-academics for their roles (Deem 2003). Also recommended are mentoring, leadership development, specific technical skills training, and opportunities for mobility including rotations and secondments. There also seems to be a strong need for proactive career planning on the part of both women and universities to address lack of career mobility. 
Mentoring should not be confined to senior women but should shape women at lower levels to move into the middle. Mentoring improves women's attachment, keeps them in higher education (Falkenberg 2003), supports their advancement (Jawahar and Hemmasi 2006) and increases their research productivity (Evans and Cokley 2008). The benefits of mentoring in higher education are not limited to the mentee. Mentors reported improved networks, satisfaction from assisting others' development, connection to the wider university agenda and improved interpersonal skills (de Vries, Webb and Eveline 2006).

From a sector-wide perspective there needs to be more action instigating a legitimate resourcesbased view of strategy which values and develops middle-managers' human capital. Further HRD research should continue to investigate diversity issues. Why do some individuals receive more development than others? There is a moral obligation to ensure equal access to development and career opportunities (van der Sluis 2007).

EOWA (2008) reported that women are underutilized in the workforce and that strategies to attract, engage and retain 'generation $\mathrm{f}$ ' are essential to solving the skills shortage. The existence of a 'boys club' and men advancing faster than women were perceived as workplace issues inhibiting women's employment or retention.

\section{CONCLUSION}

We believe the research is justified as one of the few national investigations into university female middle-managers and HRD. It is significant for at least four reasons: identifying the ageing demographic of this cohort, the absence or low incidence of HRD in the face of the pending skills shortage, the low mobility of women, and future business challenges to the sector given the apparent non-strategic, non resource based view of female middle-management development. Institutions simply cannot afford to neglect the development of middle-managers.

Despite recent focus on the development of senior executive women in Australian universities, the impact for the middle-managers in this study seems to be patchy. Development for some women has been taken to heart, especially in the technology universities. However, there also seem to be a large number of universities currently doing little, with negative implications for women's advancement, gender balance, sustainability and combating the skills shortage.

The middle-managers in this study need further learning and development opportunities to step up to more senior roles and in turn should be mentoring women at lower levels to pass on their considerable experience, which otherwise may be lost. Individual and organization planning for career mobility and pending retirement are indicated. New imperatives demand a strategic approach to HRD in universities. The evidence from our research suggests that higher education institutions could do more to invest in human capital through HRD and exhibit more forwardthinking initiatives, particularly if they profess to be learning organizations. 


\section{References}

Asquith, J., Sardo, S., and Begley, P. (2008). 'Love 'em don’t lose 'em'- identifying retention strategies that work', HRpulse Research Report, AHRI, 2(1).

Aitkin, D. (2001). The Last Boilerhouse Address, Canberra University.

http://www.canberra.edu.au/secretariat/speeches/vcaddr25_7_01.html. Accessed 16 August 2002.

Akerlind, G. S. (2005). Academic growth and development - How do university academics experience it?, Higher Education 50(1), 1-32.

Allport C. (1996). Improving gender equity: Using industrial bargaining, NTEU Frontline, 4(1), 59.

AVCC (2004). List of senior university women - 2004. Canberra.

http://www.avcc.edu.au/database/search/senioroff.asp. Accessed 1 November 2004.

AVCC (2006). The second AVCC action plan for women employed in Australian universities (2006 -2010). Canberra. http://www.avcc.edu.au/documents/policies_programs/women/AVCCAction-Plan-for-Women-2006.pdf. Accessed 24 April 2007.

Benn, S., Dunphy, D., and Griffiths, A. (2007). Organizational change for corporate sustainability. London: Routledge.

Blackmore, J., and Sachs, J. (2000). Paradoxes of leadership and management in higher education in times of change: Some Australian reflections, International Journal of Leadership in Education, $3(1), 1-16$.

Blackmore, J., and Sachs, J. (2001). Women leaders in the restructured university, in Brooks, A. and Mackinnon, A. (Eds.). Gender and the restructured university, (pp. 45-66). Buckingham: Open University Press.

Blättel-Mink, B. (2008). Reinventing gender in higher education: Conference report, 5th European Conference on Gender Equality in Higher Education, Berlin, Germany, 28-31 August 2007. Equal Opportunities International, 27(1), 107-111.

Burke, R. J., Burgess, Z., and Fallon, B. (2006). Workaholism among Australian female managers and professionals: Job behaviors, satisfactions and psychological health. Equal Opportunities International, 25(3), 200-213. 
Caligiuri, P., Lazarova, M., and Zehetbauer, S. (2004). Top managers' national diversity and boundary spanning: Attitudinal indicators of a firm's internationalization. Journal of Management Development, 23(9), 848-859.

Castleman T., Allen M., Bastalich W., and Wright P. (1995). Limited access, women's disadvantage in higher education employment. Melbourne: NTEU.

Chao, G. T. (1990). Exploration of the conceptualization and measurement of career plateau: a comparative analysis, Journal of Management, 16(1), 181-193.

Chesterman C. (2004). Not doable jobs?' Exploring senior women's attitudes to leadership roles in universities. Women's Higher Education Network Conference, Bolton.

Chesterman, C., and Ross-Smith, A. (2006). Not tokens: reaching a 'critical mass' of senior women managers. Employee Relations, 28(6), 540-552.

Chesterman C., Ross-Smith A., and Peters M. (2003). Changing the landscape? Women in academic management in Australia. McGill Journal of Education, 38(3), 421-435.

Chesterman, C., Ross-Smith, A., and Peters, M. (2006). The gendered impact on organisations of a critical mass of women in senior management. Policy \& Society, 24(4), 69-91.

Currie J., and Thiele B. (2002). Globalization and the gendered work cultures of universities, in Brooks A., and Mackinnon A. (Eds.), Gender and the restructured university, (pp. 90-115). Buckingham: Open University Press.

Deem, R. (2003). Gender, organizational cultures and the practices of manager-academics in UK universities. Gender, Work and Organization, 10(2), 239-259.

Doherty, L., and Manfredi, S. (2006). Women's progression to senior positions in English universities. Employee Relations, 28(6), 553-572.

Dychtwald, K., and Baxter, D. (2007). Capitalizing on the new mature workforce. Public Personnel Management, 36(4), 325-334.

Ebner, A. L. (2007). Playing by the 'new rules': Contemporary feminism and gender policy in Scottish higher education. Palmetto Practitioner Journal: Issues in Student Affairs, (March).

EOWA (2008). Employer of choice for women. Canberra: Equal Opportunity in the Workplace for Women Agency. 
EOWA (2008). Generation f: attract, engage, retain. Canberra: Equal Opportunity for Women in the Workplace Agency.

Evans, G. L., and Cokley, K. O. (2008). African American women and the academy: Using career mentoring to increase research productivity. Training and Education in Professional Psychology, 2(1), 50-57.

Eveline, J. (2004). Ivory basement leadership; power and invisibility in the changing university. Perth: University of Western Australia Press.

Falkenberg, J. (2003). Decreasing numbers at increasing levels: An investigation of the gender imbalance at NHH. Gender, Work \& Organization, 10(2), 175-193.

Forster, N. (2000). The myth of the 'international manager'. The International Journal of Human Resource Management, 11(1), 126-142.

Garavan, T. N. (2007). A Strategic Perspective on Human Resource Development. Advances in Developing Human Resources, 9(1), 11-30.

Gopinathan, A. (2007). International research may leave women adrift. Nature, (448), 749.

Howell, S., Buttigleg, D. M., and Webber, W. (2006). Management attitudes to older workers in the retail sector. Monash Business Review 2(2), 4.

Ismail, M., and Rasdi, R. M. (2007). Impact of networking on career development: Experience of high-flying women academics in Malaysia. Human Resource Development International, 10(2), 153-168.

Jawahar, I. M., and Hemmasi, P. (2006). Perceived organizational support for women's advancement and turnover intentions: The mediating role of job and employer satisfaction. Women in Management Review, 21(8), 643-661.

Jo, V. (2008). Voluntary turnover and women administrators in higher education. Higher Education, in press.

Joyner K., and Preston A. (1998). Gender differences in perceptions of leadership role, performance and culture in a university: a case study. International Review of Women and Leadership, 4(2), 34-43.

Kamoche, K. (1996). Strategic human resource management within a resource-capability view of the firm, Journal of Management Studies. 33(2), 213-233. 
Kira, M., and Forslin, J. (2008). Seeking regenerative work in the post-bureaucratic transition. Journal of Organizational Change Management, 21(1), 76-91.

Kramar, R. J. (1990). Managers in Australia. Sydney: Industrial Relations Research Center, UNSW.

Krefting, L. A. (2003). Intertwined discourses of merit and gender: Evidence from academic employment in the USA. Gender, Work \& Organization, 10(2), 260-278.

Lane, B. (2008). Staff Crisis First Bill of Order. Higher Education, The Australian, April 18, p. 1

Marginson, S. (1999). Diversity and convergence in Australian higher education, Australian Universities Review, 421, 12-23.

McDonald, P. K., Bradley, L. M., and Guthrie, D. (2006). Challenging the rhetoric of choice in maternal labour-force participation: preferred versus contracted work hours. Gender, Work \& Organization, 13(5), 470-491.

Moseley, J. L., and Conway Dessinger, J. (2007). Training Older Workers and Learners. San Francisco: Wiley.

Neuman, W. L. (1994). Social research methods (2nd Ed.). Boston: Allyn and Bacon.

Niven, L. (2007). Few women join ranks of Germany's academic élite. Nature, (450), 788.

OECD (2004). Ageing societies and the looming pension crisis.

http://www.oecd.org/searchResult/0,3400,en_2649_201185_1_1_1_1_1,00.html. Accessed 11 April 2008.

Padilla, L. (2008). How has Mexican faculty been trained? A national perspective and a case study. Higher Education, 56(2), 167-183.

Priola, V. (2004). Gender and feminine identities - women as managers in a UK academic institution. Women in Management Review, 19(8), 421-430.

Probert, B., Ewer, P., and Whiting, K. (1998). Gender pay equity in Australian higher education. Melbourne: NTEU.

Probert, B. (2005). I just couldn't fit it in: Gender and unequal outcomes in academic careers.

Gender, Work and Organization, 12(1), 50-72. 
Ramsay, E. (2000). Women and leadership in higher education: Facing international challenges and maximizing opportunities. Keynote address at Asian Women Leaders in Higher Education 2, University Kebangsaan, Malaysia, Kuala Lumpur, October.

Roomkin, M. J. (1989). Managers as Employees. New York: Oxford University Press.

Rosser, V. J. (2004). A national study on midlevel leaders in higher education: The unsung professionals in the academy. Higher Education, 48, 317-337.

Santiago, R., Carvalho, T., Amaral, A., and Meek, V. L. (2006). Changing patterns in the middle management of higher education institutions: The case of Portugal. Higher Education, 52, 215250.

Subramaniam, N. (2003). Factors affecting the career progress of academic accountants in Australia: Cross-institutional and gender perspectives. Higher Education, 46, 507-542.

UNESCO (2002). Women and management in higher education: a good practice handbook. Paris: OECD.

van den Brink, M., Brouns, M., and Waslander, S. (2006). Does excellence have a gender? A national research study on recruitment and selection procedures for professorial appointments in The Netherlands. Employee Relations, 28(6), 523-539.

van der Sluis, L. E. C. (2007). Umbrella for research into human resource development (HRD). Human Resource Development International, 10(1), 99 - 106.

van Gellecum, Y., Baxter, J., and Western, M. (2008). Neoliberalism, gender inequality and the Australian labour market. Journal of Sociology, 44(1), 45-63.

Veiga, J. F. (1983). Mobility influences during managerial career stages. Academy of Management Journal, 26(1), 64-85.

Wallace, M. (2003). Policy and organizational discourses: Identities offered to women workers. Equal Opportunities International, 22(1), 50-77.

Wallace, M. (2006).The paradox and the price: a case study of female academic managers in an Australian regional university. Advancing Women in Leadership, 21, Fall. http://www.advancingwomen.com/awl/summer2006/Wallace.html. Accessed 6 June 2007.

Wang, G. G., and Holton, E. F. (2005). Neoclassical and institutional economics as foundations for human resource development theory. Human Resource Development Review, 4(1), 86. 
Watkins, K., E. (2005). What would be different if higher educational institutions were learning organizations? Advances in Developing Human Resources, 7(3), 414.

Wayne, S. J., Liden, R. C., Kraimer, M. L., and Graf, I. K. (1999). The role of human capital, motivation and supervisor sponsorship in predicting career success. Journal of Organizational Behavior, 20(5), 577-595.

Wentling, R. (2003). The career development and aspirations of women in middle management revisited. Women in Management Review, 18(5/6), 311-325.

Werner, J.M., and DeSimone, R.L. (2006). Human resource development. (4th Edn.). Melbourne: Thomson South-Western.

White, K. (2003).Women and leadership in higher education in Australia. Tertiary Education and Management, 9(1), 45-60.

Wyn, J., Acker, S., and Richards, E. (1997). Making a difference: women in management in Australian and Canadian faculties of education. Gender and Education, 12(4), 435-447. 